8. Shubravsjka, M. M. (1972). D. I. Javornycjkyj. Zhyttja, foljklorystychno-etnoghrafichna dijaljnistj. Kyiv : Naukova dumka. [In

9. Evarnitskiy, D. I. (1906). Malorossiyskie narodnye pesni, sobrannye v 1878-1905 gg. Yekaterinoslav: Tipografiya Gubernskago Zemstva. [In Russian].

Стаття надійшла до редакції 24.10.2018 p.

UDC 78.071.2/784.3

Chernoivanenko Alla

Candidate of Arts, Associate Professor, Professor of the Department of Folk Instruments of A.V. Nezhdanova Odessa National

Musical Academy

ORCID 0000-0001-8413-6172

alla_ch-ko@ukr.net

\title{
PERFORMING SEMANTICS OF SILENCE IN INSTRUMENTAL MUSIC OF THE XX-XXI CENTURIES
}

The purpose of the article. The research is connected with identification of semantic values of silence by musical and instrumental performance means. The methodology of a research consists in application of the historical and culturological, logic and semantic, esthetic, historical and logical, generalizing methods. Important musical and textual, analytical musicological and performing approaches are represented. All of them create unified methodological base of a research. The scientific novelty of work consists in expansion of ideas of figurative and semantic value of silence in instrumental music of XX - XXI centuries. Special "absoluteness" of silence in a musical-performing as "other being" of the thematic and sound values corresponding to procedurality of musical thinking, the nature of a musical chronotope and instrumental playing movements is approved. Conclusions. Understanding of philosophical, psychological, aesthetic, musicological and musical-performing meanings of silence and a pause in music brings to new semantic paradigms of art of the second half of XX - beginning of the XXI centuries. Forms of musical instrumental performing movements of "silence music" (a play in air, silent pressing of keys or valves of the instrument, etc.), the absoluteness of instrumental silence, its dramatized evident exaggeration embody the other being of loud tones and thematic structures in their art variety. Semantic range of an imagesymbol of silence fluctuates in music from intimate and trembling to philosophical, from expressive-strained to pacified.

Keywords: silence; pause; semantics of silence; silence; performer; musical chronotope; musical and instrumental "absoluteness" of silence.

Черноиваненко Алла Дмитриевна, кандидат искусствоведения, доцент, профессор кафредры народных инструментов Одесской национальной музыкальной академии им. А.В. Неждановой

Виконавська семантика тиші в інструментальній музиці XX-XXI століть

Мета роботи. Дослідження пов'язане з виявленням семантичних значень тиші засобами музично-інструментального виконавства. Методологія дослідження полягає в застосуванні історико-культурологічного, логіко-семантичного, естетичного, історико-логічного, узагальнюючого методів. Важливими видаються музично-текстологічний, аналітичний музикознавчий та виконавський підходи. Разом вони створюють єдину методологічну базу дослідження. Наукова новизна роботи полягає в розширенні уявлень про образно-семантичному значенні тиші в інструментальній музиці XX - XXI століть. Стверджується спеціальна «абсолютність» тиші в музично-інструментальному виконавстві як «інобуття» тематично-звукових значень, що відповідають процесуальності музичного мислення, природі музичного хронотопу, інструментально-ігрових рухів. Висновки. Осмислення філософських, психологічних, естетичних, музикознавчих та інструментально-виконавських смислів тиші і паузи в музиці виводить на нові семантичні парадигми мистецтва другої половини XX - початку XXI ст. Форми музично-інструментальних виконавських рухів «музики тиші» (гра в повітрі, беззвучне натискання клавіш або клапанів інструменту і т.д.), абсолютність інструментальної тиші, ї̈ театралізована наочна гіперболізація втілюють інобуття звучних тонів і тематичних структур в їх художньому різноманітті. Семантичний діапазон образу-символу тиші коливається в музиці від інтимно-трепетного до філософрського, від експресивно-напруженого до умиротвореного.

Ключові слова: тиша; пауза; семантика тиші; мовчання; виконавець; музичний хронотоп; музично-інструментальна «абсолютність» тиші.

Черноиваненко Алла Дмитриевна, кандидат искусствоведения, доцент, профессор кафедры народных инструментов Одесской национальной музыкальной академии им. А.В. Неждановой

Исполнительская семантика тишины в инструментальной музыке XX-XXI веков

Цель работы. Исследование связано с выявлением семантических значений тишины средствами музыкальноинструментального исполнительства. Методология исследования заключается в применении историко-культурологического, логико-семантического, эстетического, историко-логического, обобщающего методов. Важными представляются музыкальнотекстологический, аналитический музыковедческий и исполнительский подходы. Вместе они создают единую методологическую базу исследования. Научная новизна работы заключается в расширении представлений об образно-семантическом значении тишины в инструментальной музыке XX - XXI веков. Утверждается специальная «абсолютность» тишины в музыкальноинструментальном исполнительстве как «инобытие» тематически-звуковых значений, соответствующих процессуальности музыкального мышления, природе музыкального хронотопа, инструментально-игровых движений. Выводы. Осмысление философских, психологических, эстетических, музыковедческих и инструментально-исполнительских смыслов тишины и паузы в музыке выводит на новые семантические парадигмы искусства второй половины XX - начала XXI вв. Формы музыкальноинструментальных исполнительских движений «музыки тишины» (игра в воздухе, беззвучное нажатие клавиш или клапанов инструмента и т.д.), абсолютность инструментальной тишины, ее театрализованная наглядная гиперболизация воплощают инобытие громких тонов и тематических структур в их художественном многообразии. Семантический диапазон образасимвола тишины колеблется в музыке от интимно-трепетного до философрского, от экспрессивно-напряженного к умиротворенному.

Ключевые слова: тишина; пауза; семантика тишины; молчание; исполнитель; музыкальный хронотоп; музыкальноинструментальная «абсолютность» тишины.

(c) Chernoivanenko A., 2019 
Relevance of the research. In the permanently accelerating modern space of life, culture and art in the context of globalization, increasing information and psychological tensions, a certain sound and anthropogenic aggression of today, the topic of silence, pause, rest, peace becomes more and more relevant. The natural need for silence is embedded in the psychology of each person as a sign of "peace" and "quietude", spiritual balance, contemplation, mystery. In religion, it has been elevated to the rank of spiritual and semantic quality, as the manifestation of the Holy Spirit, marking its isolation from civilization, manifesting the secrecy of the sound of prayer, the appeal to God, and cathartic states. Finally, in art, silence carries an important psychological and dramatic load in contrasting techniques of dynamic deployment, in the ability to take the form of that with which it comes into contact, without losing its own integrity of tangible ("audible" and "visible") images, paintings, signs that, "with their sacral perfection fill the world with spiritual states and meanings" [2], demonstrating the quality of ambivalence with the ability to express a variety of emotions, feelings, situations and phenomena. The commonality of all these various manifestations of silence is based on a positive, bright (perhaps tragically bright), harmonious, spiritually directed beginning, acting as a symbol of the integrity of being. Such a contemplative direction acquired a new impetus for development at the end of the twentieth century, which was reflected in the strengthening of the individual-subjective beginning, the importance of the lyrical component in the statement of the principles of stylistic synthesis, the search for metalinguistic universals and - promotion of silence and silence as a new informative-semantic element. "Due to its intangible essence, silence easily becomes the" material "of any kind of art, an element of any sign system, without losing the basic property - the inexhaustibility of content" [7].

Actually, the actualization of silence, the crystallization of its expressive means and their semantic meanings in the music of the late XX - early XXI centuries largely transformed the experience of other forms of art, formed in the figurative-semantic field of various historical, artistic and proper musical phenomena (it is worth noting that the famous expression of the composer called S. Gounod "good does not produce noise, and noise does not produce good" had multiple options in different historical eras and in different contextual fields - from the religious and moral ideal of "hosts" to post-modern "void" and" silence"). But it was postmodernism that made silence, soundlessness, emptiness, etc., symbolic modes of the modern consciousness (and art). And "the stability of their manifestation allows us to perceive these "through motives" as certain "tools of analysis" of an era or an individual style" [7, 4].

I. Nekrasova argues that the attitude to silence (or "relationship with silence" - A.C.) reflects the essence of its "spiritual and aesthetic atmosphere in different historical epochs, indicates the state of social psychology, the dynamics of social processes" [ibid.]. In culture and art, there is a visible alternation of "analytical and synthetic types of thinking", "hard" and "soft" styles (for example, the asceticism of the Middle Ages is replaced by the bright dynamics of the Renaissance; the period of the 18th and early 19th centuries by the romantic "flight into silence"; refined Silver Age aestheticism - by cataclysms and shocks of the XX, etc.). And if in the era of Romanticism silence (except the conclusion about the impotence of speech in "the expression of the ineffable" - "the spoken idea is a lie") becomes a common denominator, a kind of Esperanto, overcoming the differences of arts in their necessary synthesis, then in the new concept of modernist and postmodernist aesthetics the "expansion of silence "(actively noted already by musicologists, starting from B. Asafiev, F. Busoni, L. Sabaneev, P. Suvchinskyi) marks a turn from the extraverted type of artistic expression towards the emancipation of its introspective beginnings. It is characteristic that in the last third of the twentieth century silence was perceived not only as a landmark sign of composer thinking, but also as "the most mysterious category of new performing poetics" (V. Chinaev [8, 32]).

Thus, silence includes a lot of philosophical, psychological, cultural, aesthetic, musical and sound meanings, which often contain the truth and integrity of life, the core indicators of artistic concepts, bright intonation and language techniques, which is confirmed by composer searches in the designated area. Elucidation of the specific semantic and musical-linguistic parameters of silence is an urgent task of modern musicological research.

The purpose of the article is to identify and analyze the semantic features of silence and peace by means of musical instrumentalism. The scientific novelty consists in asserting the quality of specific absoluteness of instrumental silence as symbols of the denial of the earth's phonosphere and as conjugation with the beyond, the "otherness" of sound and thematism, in full accordance with the laws of the processuality of musical thinking.

The presentation of the main material. In recent decades, the phenomenon of silence in music in one way or another is related to a large part of musicological, compositional and performing research. Performance judgments are especially valuable here. These are the performers, who demonstrate silence with their play - on the one hand, because silence as an actual means of expressing postmodern tendencies manifests itself, to a greater extent, in instrumental music, the performing process of which is denoted by the notion "play", on the other hand, in performing the silence of theatrically-playing component plays a key role in identifying the musical processuality, meaning, because the metaphysicality and clarity of silence and pauses are fully revealed in the game art space. The play, as well as the performance, as well as the processuality of the musical meaning (according to B. Asafiev), has a temporal characteristic, tempo-metrorhythmic pulsation and structuring, in which various levels and techniques corresponding to the dramatic one 
are defined. To identify such semantic levels of silence in the composer's idea (and recently, the expressive potential of silence is used as a stable style mark), there is the performing "birth of sound from silence", its variously colored figurative and semantic reproduction (including in caesuras and pauses), mastering the skill "to stop consciously", etc., that not only draws up an individual performing decision, but also contributes to the birth of such means in the composer's language. Thus, the expressive possibilities of silence in musical art are determined, first of all, by its performing potential, which relies on a living, instrumentally tangible, mental-procedural, and stage-artistic experience in interpreting the various sound semantic structures of music. Outside such an experience, the musical-instrumental "silence" loses its semantic expressive bases. In this regard, it is interesting to observe the Odessa composer K. Maidenberg-Todorova over the listening reaction to the performance of the "classics of silence" - "4'33" J. Cage: during the tense waiting for some musical events, even being informed that in the visible-audible nothing will happen in the space of the concert hall, listeners become active participants of the "Cage game" [6].

The concept of silence, pause (as well as sounding tone) in music is in a qualitative relationship with the category of time. In this aspect, and also in line with the qualitative (qualifying) concept of time, the Bergson's term "durée" that is inaccurately translated into Russian - "duration" (a discrete element of the musical fabric, without regard to processuality) takes on special significance. V. Vernadskyi translated it as a "report", expressing Bergson's main processual intention about time; qualitative, non-discrete nature of the temporal deployment of music. In general, in the historical context, the idea of time is informative. Bergson has already drawn conclusions about the universal nature of the "vision" and connected it with the evolutionary essence of the world (including biological) formation as a creative process. Vernadskyi said that "the line between psychological and physical time is erased" [3, 45]. Here it would be appropriate to draw a parallel with the "involvement" of pauses, silence in the sphere of musical instrumentalism. Hands of the performer, as a rule, at such a moment either theatrically "freeze" (do not stop, but cease to contact with the keyboard, string, etc.), or demonstrate some theatrical acting gestures outside instrumental (conducting a pause, "removing" the instrument, damping of the strings in a pinch, etc.) or directly of an instrumental nature (playing "in the air", on the fretless part of the neck of the pinch) —that is, a space-time "separation" from sounding matter and materiality, physicality occurs in the total time continuum of music, a kind of suggestion from the audience and the performers with simulated calculation of the game on "understanding of dealing." The extreme expression of such instrumental physicality is "4.33" by J. Cage, "A Minute of Silence" by E. Kislitsyn, or the "silent performance" of M. Theodorakis's forbidden song with the "silent" guitar in his hands, when the whole composition is the embodied pause. The instrument itself, its "life" (as the purpose of artistic sound) at the moment of silence in the hands of the performer, clearly demonstrates (enhances) "absolute silence" (the vocalist with the "built-in instrument" - breathes, as during the sound, moves, looks, can cough and etc .: his silence is "not absolute") and, at the same time, complete objective (independent of human physiological processes) freedom to move from a state of silence to a state of sound. Thus, a musical instrument seems to exaggerate the phenomenon, "making" it, with the manifestation of skill ("the skill of artificial"). The hyperbolization of silence is also associated with the ability to enhance the contrast between silence and sound due to the density of texture, dynamics, articulation and timbre parameters.

The concept of time of M. Arkadiev suggests "learning to rebuild our consciousness from school habits to think of time as a pure and process-independent duration, to stop thinking of it as an irrelevant and abstract flow, which is not so simple" $[1,133]$. The synonymy of time and process, the continuity-processuality of twentieth-century theorists of physics is combined with B. Asafiev's intonation processuality in music, with the idea of becoming the key for musical development (especially in "pure", instrumental music). And if in the vocal processuality of music there is a connection with the continuum processual breathing, heartbeat (physiology), then the processual musical instrumental (performing-doing) imposes (stratifies) some kind of independent from the life of one person (performer, composer, listener) - objective processuality, "real and concrete processes in the world" with its variability, a reflection of the universal process "tarries" (BergsonHusserl), "temporary matter" (M. Arkadiev). In the process of execution, the instrument in a certain sense itself acts as a "temporary" matter in the hands of the performer. Spatiality, texture, articulation-dynamic relief on the instrument also "tarries", it becomes. Therefore, it is natural that the absolutist expression of the qualitative concept of time in music was embodied not in vocal, but in instrumental work of J. Cage.

A distinctive feature of the instrumental performance is the visibility of its intonation-motor side, forms of performing movements and instrumentally-sound techniques, also in the sphere of silence (in the singing this "mechanism" is hidden from the listener-viewer). In musical instrumentalism, such processes are visible and perceived in this quality even without hearing music (for example, if you turn off the sound while saving video "pictures"). This feature was skillfully used by A. Schnittke in the "cadenza-visual" of the Fourth Violin Concert, when the violinist plays in an ever-higher tessiture and, finally, as if escaping beyond the limits of the possible, "plays" in the air. Expressive, meaningful movement - "quasi-sounding" - continues in silence, in the quiet play of fingers, goes into the area of "pure content". Such an intonational illusion rests on the accompanying visual images and the listening experience of the listener, on the timbre-style arsenal of the instrument. Also, with sufficiently long pauses between loud tones or chords, the performing movements (or their sudden "lag") remain alone with silence and internal auditory imagination. Such a pause is filled with intonation (semantic) content, and the picture of instrumental intonation turns out to be phenomenologically 
opposite to singing. If in the first "hand breathing" is represented visually, then in the second the breath is hidden and "impersonates itself" in artistic vibration, only in caesuras manifesting itself directly.

Conclusions. A musical instrument is a materialized embodiment of the artistic syncresis in which music was developing. Materializing the ideal sound images and representations, the musical instrument itself is able to form new musical and sound ideas in the field of "pure content", without the mediation of the word. Already while production, live proto-intonation (V. Medushevskyi) is "embedded" in the instrument and, at the same time, artistic (skillful) sound / silence parameters are elegantly polished. The composer continues this process. But the real life is breathed into the musical instrument by the performer. Thus, the instrument is a kind of potential musical space with different possibilities, the composer, and even more specifically, the performer is organized in a certain process, in a chronotope in accordance with his individual unique (composer and performing) concept. And here the ratio of total / individual acts in an ambivalent and mutually reversible quality. Protointonation as a generalized semantic-sound formula of a work does not simply include the signs of silence. The phenomenon of protointonation refers us to silence as a symbol of integrity, it translates the ancient meanings of being. In the second half of the twentieth and early twenty-first centuries, silence becomes a universal phenomenon, and in musical culture plays the most important role in the structural and semantic organization of the composition.

In music, the phenomenon of silence is mainly realized in instrumental music. This is due to a more pronounced contrast (textural, dynamic, range, gesturally theatrical) sound / silence, the lack of background elements of human silence (breathing, cough, spontaneous movement, etc.) with simultaneous objective, technically and physiologically independent readiness (possibility) move from silence to the state of sound. The instrument, even in a state of silence, personifies not just the potential sound, but the sound itself is artistic (as opposed to the possible vocal speech of a vocalist). At the same time, instrumental silence captures the specific absoluteness of silence (with complete denial of the terrestrial sound environment - breathing, spontaneous movement, cough, etc.) as a collision with the beyond, as the "otherness" of sound and thematism $[4 ; 5]$, and not their non-existence, fully corresponds to the processuality of musical thinking, the nature of the musical chronotope.

The visibility of the intonation-motor side of instrumental music playing, forms of performing movements and instrumental-sound techniques, the quality of the instrument's "tarrying" matter allows silence to be perceived as "silence with meaning", and performing movements (or their sudden "hang") remaining alone with silence and internal auditory imagination creates an intonational-sense pause. Forms of musical and instrumental performing movements (playing in the air, silent pressing of keys or instrument valves, etc.), the absoluteness of instrumental silence, its theatrical visual hyperbolization embody the otherness of loud tones and themes in their artistic diversity: silence as the disappearance of matter and "unity with the Absolute "(the failed project of A. Scriabin" Absolute Pause"), as the non-musical sound of the outside world (J. Cage's 4'33)," silence with meaning" (collision with the infinite) and "silence with quietude of the gone" ("Misterio" by V. Silvestrov for clarinet-solo), gracious peace, intense waiting, immersion in a dream-oblivion, romantic dream, etc.

\section{תimepamypa}

1. Аркадьев, М.О. Лингвистическая катастрофра (Антропология абсурда: новый стоицизм). М., 2011. 279 с.

2. Барсукова, Т.В. Метафизика паузы в художественно-творческой игре. Вестник Челябинского государственного университета: Философия. Социология. Культурология. Челябинск: ЧГУ, 2010. № 31 (212). Вып. 19. С. 68-72.

3. Вернадский, В.И. Размышления натуралиста. Пространство и время в неживой и живой природе. М.: Наука, 1975.

$368 \mathrm{c}$.

4. Зинькевич, E.C. Музыка как молчание. URL: : http://jgreenlamp.narod.ru/muzykamolchanije.htm

5. Кириллина, Л.В. Идея развития в музыке XX века. Западное искусство. XX век: Проблема развития западного искусства XX века. СПб: Дмитрий Буланин, 2001. С. 101-126.

6. Майденберг-Тодорова, К.І. Тиша як полісемантичний феномен: композиторські та виконавські способи втілення. Часопис Національної музичної академії України імені П.І. Чайковського. № 1. 2013. 66-72.

7. Некрасова, И.М. Поэтика тишины в отечественной музыке 70-90-х гг. XX века. автореф. дисс. .... канд. искусствоведения: 17.00.02 / М.. 2005. 26 c. URL : http://cheloveknauka.com/poetika-tishiny-v-otechestvennoy-muzyke-70-90-h-gg-xx-veka

8. Чинаев В. Время Пространство - Мгновение. Сов. музыка. 1991. №7. С. 31-36.

\section{References}

1. Arkadiev, M.O. (2011). Linguistic catastrophe (Anthropology of the absurd: a new stoicism). Moscow [in Russian].

2. Barsukova, T.V. (2010). The metaphysics of a pause in an artistic and creative game. Bulletin of the Chelyabinsk State University: Philosophy. Sociology. Culturology. Chelyabinsk: Chelyabinsk State University, № 31 (212). Issue. 19. P. 68-72 [in Russian].

3. Vernadsky, V.I. (1975) Reflections of the naturalist. Space and time in inanimate and living nature. Moscow: Nauka [in Russian].

4. Zinkevich, E.S. Music is like silence. URL: http://jgreenlamp.narod.ru/muzykamolchanije.htm [in Russian].

5. Kirillina, L.V. (2001) The idea of development in the music of the twentieth century. Western art. XX century: The problem of the development of Western art of the twentieth century. SPb: Dmitry Bulanin. P. 101-126 [in Russian].

6. Maydenberg-Todorova, K.I. (2013). Silence as a polysemantic phenomenon: composing and performing ways of embodiment. Journal of the National Music Academy of Ukraine named after PI Tchaikovsky No. 1. 2013. 66-72 [in Ukrainian].

7. Nekrasova, I.M. (2005). Poetics of silence in the domestic music of the 70-90's. XX century. Extended abstract of candidate's thesis. Moscow. URL: http://cheloveknauka.com/poetika-tishiny-v-otechestvennoy-muzyke-70-90-h-gg-xx-veka [in Russian].

8. Chinaev V. (1991). Time Space - Instant. Ow. music. No. 7. 31-36 [in Russian] 